\title{
Burnout and sources of stress among medical residents at Hamad Medical Corporation, Qatar
}

Abdelhamid Afana ${ }^{1}$, Jess Ghannam ${ }^{2}$, Evelyn Y. Ho ${ }^{3}$, Abdullatif Al-Khal ${ }^{4}$, Banan Al-Arab ${ }^{4}$ and Carma L. Bylund ${ }^{4}$

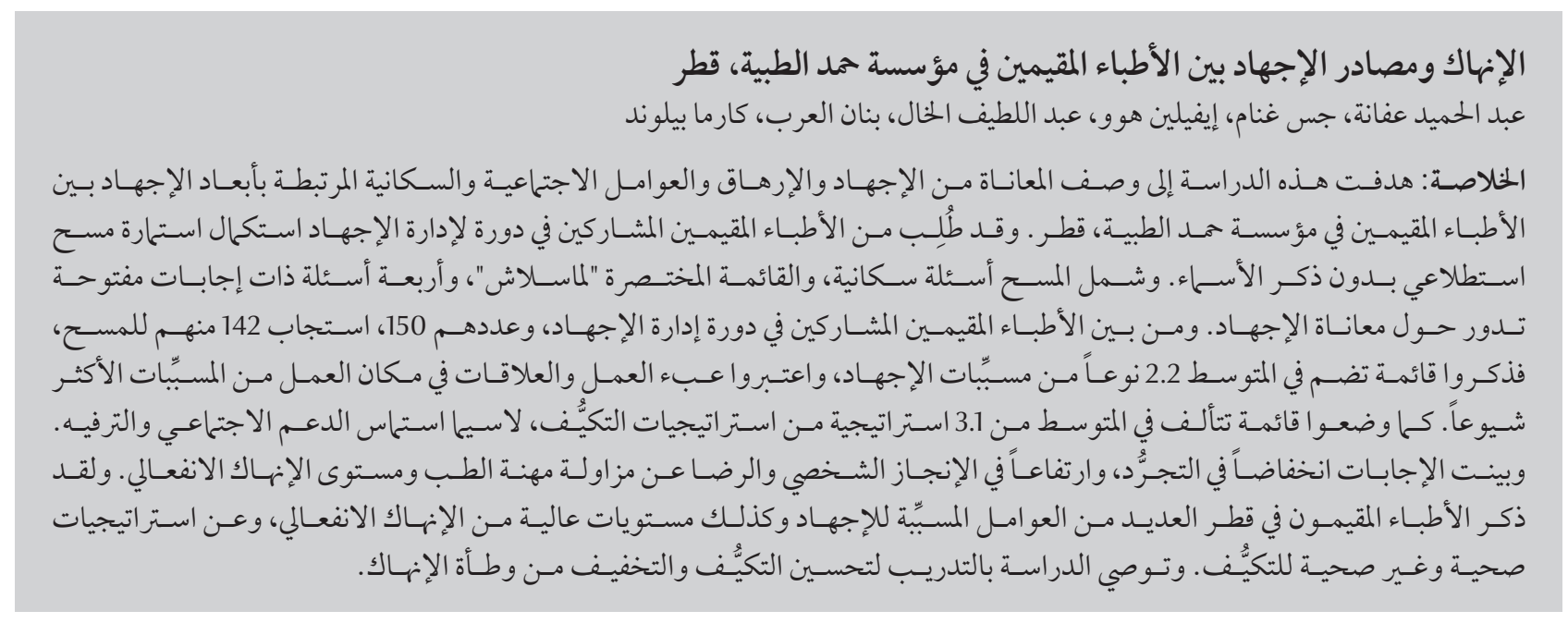

ABSTRACT This study aimed to describe the experiences of stress and burnout and sociodemographic factors associated with dimensions of stress among medical residents at Hamad Medical Corporation, Qatar. Medical residents participating in a stress management course were asked to complete an anonymous survey. The survey included demographic questions, the Abbreviated Maslach Inventory, and 4 open-ended questions on experiences with stress. Of the 150 residents participating in the stress management course, 142 responded to the survey, listing an average of 2.2 types of stressors, with workload and workplace relationships as the most frequent. They listed an average of 3.1 coping strategies, most frequently seeking out social support and entertainment. Responses indicated low depersonalization, high personal accomplishment, high satisfaction with medicine and high emotional exhaustion. Training to improve coping and reduce burnout is recommended.

\section{Épuisement professionnel et sources de stress parmi les internes en médecine de la Hamad Medical Corporation, Qatar}

RÉSUMÉ La présente étude avait pour objectif de décrire les expériences de stress et d'épuisement professionnel ainsi que les facteurs socio-démographiques associés à l'existence de ce stress parmi les internes en médecine de la Hamad Medical Corporation, au Qatar. Il a été demandé à des internes en médecine participant à un cours de gestion du stress de répondre à une étude anonyme. L'étude incluait des questions d'ordre démographique, la version abrégée de l'inventaire de burnout de Maslach et 4 questions ouvertes sur les expériences de stress. Sur les 150 internes prenant part au cours sur la gestion du stress, 142 ont répondu à l'étude, énumérant une moyenne de 2,2 types de facteurs de stress, à savoir, pour les plus fréquents, la charge de travail et les relations sur le lieu de travail. Ils ont également énuméré une moyenne de 3,1 stratégies d'adaptation, consistant le plus souvent à bénéficier d'un soutien social et à avoir des d'activités divertissantes. Les réponses indiquaient une faible dépersonnalisation, un fort sentiment de réalisation personnelle, un degré de satisfaction élevé concernant le domaine de la médecine et un épuisement émotionnel important. Des formations visant à améliorer l'aptitude des internes à faire face au stress et à l'épuisement professionnel ainsi qu'à réduire ce dernier sont recommandées.

${ }^{7}$ Department of Psychiatry; ${ }^{4}$ Department of Medical Education, Hamad Medical Corporation, Doha, Qatar (Correspondence to: C.L. Bylund: clincoln@hamad.qa). 2Department of Psychiatry and Global Health Sciences, School of Medicine, University of California - San Francisco, San Francisco, United States of America. ${ }^{3}$ Department of Communication Studies, College of Arts and Sciences, University of San Francisco, San Francisco, United States of America.

Received: 18/08/16; accepted: 16/10/16 


\section{Introduction}

Medical residents experience exceptional stress during their training programmes (1-3). Burnout, defined as a state of physical, mental and emotional exhaustion caused by constant exposure to stress, may occur due to long working hours, heavy workload, poor work environment, lack of social support, problems of relocation, and difficult patients and families $(1,4-6)$.

Burnout interferes with residents' ability to establish effective therapeutic relationships with patients and families, and their decision-making and diagnoses (2). Burnout is also associated with insomnia, fatigue, headaches, gastrointestinal distress, irritability, decreased concentration and medical errors $(7,8)$.

In Qatar there is a very diverse, multicultural and expatriate population of medical residents. This wide diversity may result in some unique stressors and stresses. Therefore, our aim was to investigate stress and burnout among medical residents in Qatar and to describe correlating sociodemographic factors.

\section{Methods}

\section{Study setting and participants}

This study was carried out in January 2015 at Hamad Medical Corporation (HMC) in Qatar. HMC, the country's not-for-profit healthcare system, provides healthcare services and manages 8 public hospitals. In 2012, HMC received institutional accreditation from the Accreditation Council of Graduate Medical Education in the United States of America. More than 90\% of HMC's approximately 580 residents are expatriates.

One hundred and fifty (150) residents from 19 training programmes at HMC participated in a required stress management course. They were selected by their residency programmes to take the course primarily based upon rotation schedules. They were asked to complete an anonymous, self-completed, paper-pencil survey immediately before the course as a baseline assessment for the course.

\section{Research instrument}

The mixed-methods survey first asked residents to describe their sources of stress, main coping strategies and reactions to stressors through 4 open-ended questions. The second part consisted of sociodemographic characteristics and the Abbreviated Maslach Inventory (AMI), a standardized questionnaire to assess burnout. This 12 -item scale is composed of 9 items from the Maslach Burnout Inventory and a 3-item Satisfaction with Medicine scale $(9,10)$. The 4 subscales have 3 items each: Personal Accomplishment, Emotional Exhaustion, Depersonalization and Satisfaction with Medicine. The items are answered in terms of frequency ranging from 6 "every day" to 0 "never". The questionnaire was in English, the primary language of education at HMC.

\section{Data analyses}

Two authors created a coding schema for each question based upon open coding. Each independently coded $20 \%$ of the data. Kappa statistics from comparing their coding were acceptable (0.84 and higher). Each then independently coded the remaining data and reconciled disagreements.

The AMI was scored using published instructions (11). Independent sample $t$-tests and ANOVA tests examined associations between demographic characteristics and burnout scores.

\section{Ethical considerations}

The HMC Institutional Review Board granted approval to conduct and publish the study. The purpose of the study was explained to the residents. They were informed that there would be no adverse consequences for those who did not want to participate. All information related to participants' identity is confidential and the survey did not ask for identifying information.

\section{Results}

Of the 150 residents participating in the stress management course, 142 (94.7\%) responded to the survey.

\begin{tabular}{|c|c|c|c|}
\hline Characteristic & No. & $\%$ & Percentage for all residents \\
\hline \multicolumn{4}{|l|}{$\operatorname{Sex}(n=136)$} \\
\hline Male & 92 & 68 & 69 \\
\hline Female & 44 & 32 & 31 \\
\hline \multicolumn{4}{|c|}{ Year of residency $(n=142)$} \\
\hline 1 & 33 & 23 & 26 \\
\hline 2 & 40 & 28 & 27 \\
\hline 3 & 38 & 27 & 23 \\
\hline $4+$ & 31 & 22 & 24 \\
\hline \multicolumn{4}{|c|}{ Marital status $(n=141)$} \\
\hline Married & 90 & 64 & $\square$ \\
\hline Single & 51 & 36 & $\square$ \\
\hline \multicolumn{4}{|c|}{ Parental status $(n=129)$} \\
\hline No children & 71 & 55 & $\square$ \\
\hline 1 child & 39 & 30 & $\square$ \\
\hline 2 children & 15 & 12 & $\square$ \\
\hline$>2$ children & 4 & 3 & $\square$ \\
\hline
\end{tabular}

Data were missing for some variables. 
Table 1 displays the residents' characteristics. The respondents did not differ significantly on gender or residency year from the total population of residents at $\operatorname{HMC}(\approx 580)$.

The average number of stressors listed per resident was 2.2. There were 3 main categories of causes of stress (Table 2). Work-related issues concerning workload and work relationships were the most common, with long working hours, high patient loads, and communication with other health care providers being among the stressors cited. For personal care and achievements, the stressors reported included sleep deprivation, lack of exercise and succeeding in exams. Stressors related to social aspects concerned family life, such as responsibilities (e.g. arranging schools for children) and the local context (e.g. obtaining visas).

The residents reported an average of 1.6 signs of stress. The most common were emotional signs (29\%), and included answers such as "become angry" and "feeling low interest in doing usual activities". The second most common were physical signs $(25 \%)$, such as headache, tachycardia and fatigue. The third most common signs were behavioural (24\%) including crying or shouting at others. Finally, cognitive signs (23\%) included being unable to concentrate or being "mentally exhausted".

Strategies for coping with stress were coded into 14 categories, with an average of 3.1 strategies per resident (Table 3). The most frequently reported strategies of coping included making use of social support (30\% of respondents), participating in some form of entertainment (30\%), sleeping (22\%) and engaging in physical activity (22\%).

Table 4 gives the mean scores of the 4 AMI subscales. We labelled scores over the midpoint (9) as high and those under the midpoint as low. Personal Accomplishment was highest (14.09, SD 3.14) followed by Satisfaction with Medicine (12.83, SD 3.95) and Emotional Exhaustion (10.66, SD 3.62). Depersonalization scores were fairly low (5.35, SD 3.86).

Females had significantly lower Depersonalization scores than did males $(P<0.01)$. Females with children had higher scores on Emotional Exhaustion than male residents with

\begin{tabular}{|c|c|c|c|}
\hline Causes of stress & $\begin{array}{c}\text { No. } \\
(n=142)\end{array}$ & $\begin{array}{l}\% \text { of } \\
\text { respondents }\end{array}$ & Examples \\
\hline \multicolumn{4}{|l|}{ Work-related issues } \\
\hline Workload & 70 & 49 & $\begin{array}{l}\text { "long work hours;" "frequent call;" "work overload;" "too much } \\
\text { patient load;" "work at home on presentations after working hours" }\end{array}$ \\
\hline Workplace relationships & 48 & 34 & $\begin{array}{l}\text { "dealing with the nurses assigned to my patients;" "pressure from } \\
\text { seniors;" "working with different consultants and colleagues each } \\
\text { with different personalities" }\end{array}$ \\
\hline Hospital systems & 17 & 12 & $\begin{array}{l}\text { "parking;" "initiating research;" "organizing scheduling of patients' } \\
\text { investigations/ procedures (e.g. MRI), consultations" }\end{array}$ \\
\hline Patient care & 23 & 16 & $\begin{array}{l}\text { "difficult relatives of patients;" "patients in pain cannot be totally } \\
\text { relieved" }\end{array}$ \\
\hline General work & 10 & & "work environment" \\
\hline \multicolumn{4}{|l|}{$\begin{array}{l}\text { Personal care and } \\
\text { achievement }\end{array}$} \\
\hline Achievement & 44 & 31 & $\begin{array}{l}\text { "need to study for exams;" "running out of time and feeling } \\
\text { incompetent to practice independently;" "trying to maintain my } \\
\text { current level in the program" }\end{array}$ \\
\hline Health/personal care & 20 & 14 & $\begin{array}{l}\text { "sleep deprivation;" "gaining weight and no time for exercise;" "not } \\
\text { in a strong relationship with Allah" }\end{array}$ \\
\hline Time management & 6 & 4 & "time mgt problems" \\
\hline \multicolumn{4}{|l|}{ Social issues } \\
\hline Family & 36 & 25 & $\begin{array}{l}\text { "arranging children to go to school;" "my parents' health as they are } \\
\text { getting older;" "my household responsibilities" }\end{array}$ \\
\hline Local context & 14 & 10 & "traffic;" "language barrier;" "problem with visa" \\
\hline Other & 18 & 13 & "past event in my life"; "things I can't control"; "social speech." \\
\hline
\end{tabular}




\begin{tabular}{|c|c|c|c|}
\hline Coping strategies & No. & $\begin{array}{l}\% \text { of respondents } \\
\quad(n=142)\end{array}$ & Examples \\
\hline Social support & 42 & 30 & $\begin{array}{l}\text { "enjoy some quality time with my kids", "try to meet my old friend", } \\
\text { "call my mom and wife" }\end{array}$ \\
\hline Entertainment & 42 & 30 & $\begin{array}{l}\text { "watch TV;" "movies", "shopping", "read a good novel", "listening to } \\
\text { music, playing video games" }\end{array}$ \\
\hline Sleep & 31 & 22 & "long hours of sleep", "having a nap" \\
\hline Physical activity & 31 & 22 & "biking, walk by the Corniche", "exercise", "sports" \\
\hline Relaxation & 26 & 18 & "relaxing taking deep breaths", "meditation" \\
\hline Managing work & 24 & 17 & $\begin{array}{l}\text { "break things I'm worried about into smaller steps", "rearrange my } \\
\text { priorities", "making schedules/checklist" }\end{array}$ \\
\hline Cognitive means & 23 & 16 & $\begin{array}{l}\text { "trying to forget what happened, hoping for betterment next time", } \\
\text { "looking at positive sides of things" }\end{array}$ \\
\hline Prayer/religion ( & 19 & 13 & "praying, reading Quran", “I read duas" \\
\hline Eat/drink & 17 & 12 & "eating", "drinking coffee" \\
\hline Alone time & 11 & 8 & "sit alone", "switch my phone to silent mode" \\
\hline Take breaks & 7 & 5 & "timeout from work", "change of scene" \\
\hline Smoke & 7 & 5 & "going out for shisha", "smoking" \\
\hline Seek help & 4 & 3 & "asking for help from seniors", "ask help from family/husband" \\
\hline Other & 24 & 17 & $\begin{array}{l}\text { "I don't know how, just getting through it and absorb it", "taking } \\
\text { medications", "avoid people who stress me" }\end{array}$ \\
\hline
\end{tabular}

children $(P<0.05)$. In addition, males with children reported better (lower) scores on Depersonalization and Emotional Exhaustion than did males without children $(P<0.05)$. First year residents scored higher on the Satisfaction with Medicine scale than did the other residents $(P<0.05)$.

\section{Discussion}

Medical residents in Qatar scored in the high range on Personal Accomplishment and Satisfaction with Medicine and in the low range on Depersonalization. However, there were high scores on Emotional Exhaustion, which is similar to studies from Saudi Arabia and Africa $(1,12)$. The qualitative results demonstrated that residents often experienced fatigue in their interpersonal interactions with others at work. This could be because more than $90 \%$ of residents in Qatar are expatriates, contributing to their stress and burnout $(13,14)$. Some residents do not speak Arabic and even those who do may find it hard to communicate in the Qatari colloquial dialect. Our findings may have implications for how medical education programmes address issues of stress and burnout, especially in settings with trainees of many different nationalities. The stressors reported were not specific to one country.

The most frequent stressors reported by the residents related to workload and working conditions. The primary coping strategies were social support, such as talking with family members, and entertainment. Various studies from different health care contexts have shown that social support is an important protective factor against work stress and burnout (15-17).

Sleeping and some physical activities were also reported strategies to deal with stress. Although these can be beneficial in responding to stress, too much sleep could be an avoidance strategy. Seeking help from seniors or other health care providers was infrequent. There may be a perception among residents that expressing coping difficulties is viewed negatively.
Our finding that women scored lower on Depersonalization is consistent with a study among residents in the United States of America (18), but not with a study among Dutch residents (16). Men with children have a remarkable buffer as they scored better than men without children on Depersonalization and better than women with children on Emotional Exhaustion. It could be that men with children are more likely to have a spouse who manages home life.

Our findings also showed that first year residents scored higher on the Satisfaction with Medicine scale than did the other residents. Perhaps residents are gradually confronted with stressors that reduce their satisfaction with their career choice of medicine over time.

Our study has some limitations and strengths. Although our response rate was high, response bias is a possibility. It is possible that the burnout scores were artificially low, as those who had higher levels of burnout may have been less likely to attend the course or to complete the survey. We also could 


\begin{tabular}{|c|c|c|c|c|}
\hline Characteristic & $\begin{array}{l}\text { Personal } \\
\text { Accomplishment } \\
(n=139)\end{array}$ & $\begin{array}{l}\text { Depersonal-ization } \\
\quad(n=138)\end{array}$ & $\begin{array}{l}\text { Emotional Exhaustion } \\
\qquad(n=136)\end{array}$ & $\begin{array}{l}\text { Satisfaction with } \\
\text { Medicine } \\
(n=139)\end{array}$ \\
\hline & Mean (SD) & Mean (SD) & Mean (SD) & Mean (SD) \\
\hline Total group & $14.09(3.14)$ & $5.35(3.86)$ & $10.66(3.62)$ & $12.83(3.95)$ \\
\hline \multicolumn{5}{|l|}{ Sex } \\
\hline Males & $13.98(3.17)$ & $6.00(3.88)$ & $10.45(3.43)$ & $12.76(3.98)$ \\
\hline Females & $14.11(3.11)$ & $4.11(3.55)^{* *}$ & $11.47(3.82)$ & $13.02(3.83)$ \\
\hline \multicolumn{5}{|l|}{ Year of residency } \\
\hline Year 1 & $13.59(3.21)$ & $4.66(3.82)$ & $10.45(4.18)$ & $14.06(3.57)$ \\
\hline Year 2 and above & $14.23(3.11)$ & $5.56(3.87)$ & $10.73(3.45)$ & $12.47(4.00)^{*}$ \\
\hline \multicolumn{5}{|l|}{ Parental status by sex } \\
\hline Males with children & 13.67 (3.73) & $4.95(3.82)$ & $9.48(3.21)$ & $13.47(3.98)$ \\
\hline Females with children & 14.39 (3.5) & $4.04(3.62)$ & $11.70(3.48)^{*}$ & $12.00(4.35)$ \\
\hline \multicolumn{5}{|l|}{ Male parental status } \\
\hline Males with children & 13.67 (3.73) & $4.95(3.82)$ & $9.48(3.21)$ & $13.47(3.98)$ \\
\hline Males with no children & $14.26(2.55)$ & $6.88(3.73)^{*}$ & $11.28(3.42)^{*}$ & $12.13(3.91)$ \\
\hline
\end{tabular}

${ }^{*} P<0.05 ;{ }^{*} P<0.01$

$S D=$ standard deviation.

not assess whether nationality or specialty impacted burnout scores due to the anonymous nature of the survey. Additionally, we were unable to assess whether expatriate residents had higher burnout scores than local residents. Although ours was not a random sample, we demonstrated that it did not differ significantly from our larger residency population on key demographic indicators. We believe this is because the residents are essentially assigned to take the course based on rotation/schedule.
However our results cannot be generalized outside of our population. The strengths of our study include it being the first to describe stress and burnout in multicultural residency programmes. Using mixed methods gave us a fuller picture of stress and burnout.

The results provide information to support medical education efforts to identify the contributing factors and consequences of burnout on patient safety and quality of care. Medical educators should provide appropriate intervention programmes to help combat stress and burnout among residents.

\section{Acknowledgements}

We would like to acknowledge the assistance of Ms Zehra Mazhar and Ms Mia Coyoca with the data collection and entry.

\section{Funding: None.}

Competing interests: None declared.

\section{References}

1. Ogundipe OA, Olagunju AT, Lasebikan VO, Coker AO. Burnout among doctors in residency training in a tertiary hospital. Asian J Psychiatr. 2014;10:27-32. PMID: 25042948

2. Ishak WW, Lederer S, Mandili C, Nikravesh R, Seligman L, Vasa $M$, et al. Burnout during residency training: A literature review. J Grad Med Educ. 2009;1(2):236-42. PMID:21975985

3. Dyrbye LN, West CP, Satele D, Boone S, Tan L, Sloan J, et al. Burnout among US Medical students, residents, and early career physicians relative to the general US Population. Acad Med. 2014;89(3):443-51. PMID: 22911330

4. West CP, Shanafelt TD, Kolars JC. Quality of life, burnout, educational debt, and medical knowledge among internal medicine residents. JAMA. 2011;306(9):952-60. PMID: 21900135

5. Castelo-Branco C, Figueras F, Eixarch E, Quereda F, Cancelo MJ, Gonzalez S, et al. Stress symptoms and burnout in obstetric and gynaecology residents. BJOG. 2007;114(1):94-8. PMID: 17233864
6. Al-Dubai SA, Rampal KG. Prevalence and associated factors of burnout among doctors in Yemen. J Occup Health. 2010;52(1):58-65. PMID: 19907108

7. Dewa CS, Loong D, Bonato S, Thanh NX, Jacobs P. How does burnout affect physician productivity? A systematic literature review. BMC Health Serv Res. 2014;14:325. PMID: 25066375

8. Kang EK, Lihm HS, Kong EH. Association of intern and resident burnout with self-reported medical errors. Korean J Fam Med. 2013;34(1):36-42. PMID: 23372904

9. McManus IC, Smithers E, Partridge P, Keeling A, Fleming PR. A levels and intelligence as predictors of medical careers in UK doctors: 20 year prospective study. BMJ. 2003;327(7407):13942. PMID: 12869457

10. McManus IC, Winder BC, Gordon D. The causal links between stress and burnout in a longitudinal study of UK. Lancet. 2002;359(9323):2089-90. 
11. Scoring the abbreviated Maslach Burnout Inventory 2015 (http://nbpsa.org/images/PRP/MaslachScoringAbbreviated. pdf, accessed 21 November 2016).

12. Al-Sareai NS, Al-Khaldi YM, Mostafa OA, Abdel-Fattah MM Magnitude and risk factors for burnout among primary health care physicians in Asir province, Saudi Arabia. East Mediterr Health J. 2013;19(5):426-34. PMID: 24617120

13. Dyrbye LN, Thomas MR, Eacker A, Harper W, Massie FS Jr, Power DV, et al. Race, ethnicity, and medical student well-being in the United States. Arch Intern Med. 2007;167(19):2103-9. PMID: 17954805

14. Thomas NK. Resident burnout. JAMA. 2004;292(23):2880-9. PMID: 15598920
15. Cohen S, Wills TA. Stress, social support, and the buffering hypothesis. Psychol Bull. 1985;98(2):310-57. PMID: 3901065

16. Prins JT, Hoekstra-Weebers JE, Gazendam-Donofrio SM, Van De Wiel HB, Sprangers F, Jaspers FC, et al. The role of social support in burnout among Dutch medical residents. Psychol Health Med. 2007;12(1):1-6. PMID: 17129928

17. Ashker VE, Penprase B, Salman A. Work-related emotional stressors and coping strategies that affect the well-being of nurses working in hemodialysis units. Nephrol Nurs J. 2012;39(3):231-6. PMID: 22866362

18. Woodside J Jr, Miller M, Floyd M, McGowen KR, Pfortmiller D. Observations on burnout in family medicine and psychiatry residents. Acad Psychiatry. 2008;32(1):13-9. PMID: 18270276 